\title{
GEOCHEMICAL MAP SHOWING DISTRIBUTION OF ANOMALOUS ELEMENT SUITES IN NONMAGNETIC HEAVY-MINERAL CONCENTRATES FROM THE CHUGACH NATIONAL FOREST, ALA SKA
}

\author{
By \\ Richard J. Goldfarb and Sarah C. Smith
}

\author{
STUDIES RELATED TO WILDERNESS
}

The Wilderness Act (Public Law 88-577, September 3, 1964) and related acts require the U.S. Geological Survey and the U.S. Bureau of Mines to survey certain areas on Federal lands to determine the mineral values, if any, that may be present. Results must be made available to the public and be submitted to the President and the Congress. This report presents the results of a geochemical survey of the Chugach National Forest, Alaska, which includes (1) the Nellie Juan-College Fiord Wilderness Study Area (Public Law 96-487, December 2, 1980); (2) those areas designated Roadless Area and classified for further planning during the Second Roadless Area Review and Evaluation (RARE II) by the U.S. Forest Service, January 1979; (3) Roadless Areas classified as nonwildern?ss; (4) national forest lands additions (under ANILCA, 1980); and (5) proposed State lands within the Chugach National Forest.

\section{INTRODUCTION}

A geochemical reconnaissance survey of the Chugach National Forest, south-central Alaska, was conducted between 1980 and 1982. The study area lies within the Kenai-Chugach Mountains and the Gulf of Alaska coastal section of the Pacific Border Ranges physiographic province (Wahrhaftig, 1965). It is the second largest national forest in the United States, roughly $9,000 \mathrm{sq} \mathrm{mi}$ in area. This area encompasses Prince William Sound, the largest Alaskan coastal embayment between Cook Inlet to the west and Cape Spencer to the southeast. Much of the region is covered by active valley and tidewater glaciers. Mount Marcus Baker, at $13,176 \mathrm{ft}$, is the highest point in the national forest. Most of the area is accessible only by helicopter or on foot, though the extensive coastline can be reached by boat.

This geochemical map delineates areas characterized by anomalous concentrations of selected elements in nonmagnetic heavy-mineral-concentrate samples. Because of the large areal extent of the Chugach National Forest and the associated large geochemical data base (Goldfarb and others, 1984), we have only distinguished broad areas characterized by multi-element geochemical signatures. Occasional point anomalies may have been excluded from the data interpretation. For more detailed data on individual sites, the reader is referred to the sample site location map and corresponding geochemical data (Goldfarb and others, 1984), as well as to the individual mineralogical maps showing the distribution of gold (Tripp and others, 1985), chalcopyrite (Goldfarb and Tripp, 1985), and barite, sphalerite, and galena (Goldfarb and others, 1985).

\section{GEOLOGIC SETTING}

The geology of the Chugach National Fcrest is dominated by two major lithologic units: the Valdez Group (Upper Cretaceous) and the Orca Group (Paleocene and Eocene?) (Nelson, Dumoulin, and Miller, 1984). The Valdez Group largely consists of rhythmically interbedded graywacke, sil'stone, mudstone, and rare pebble conglomerate. Sedimentary structures indicative of turbidites are present but are often discontinuous due to later metamorphirm and deformation. The presence of bedded tuff, pillow basalts, sheeted basalt dikes, layered gabbr?, and serpentinized dunite within the turbidite sejuence provides evidence of sea-floor volcanism simult aneous with sedimentation. The Valdez Group was accreted to the southern Alaskan continental margin by the end of Cretaceous (Plafker and others, 1977) or early Tertiary (Tysdal and Case, 1979) time. It generally is characterized by prehnite-pumpellyite to modiumgrade greenschist metamorphic facies.

The Valdez Group is bordered to the south by the Orca Group. The Orca Group is also dominated by interbedded graywacke and siltstone turbidite facies and contains subordinate tholeiitic basalt. Ths Orca Group is believed to have been accreted on to the Valdez Group sometime during the Paleocene (1"inkler and Plafker, 1975; Plafker and others, 1977). A landward-dipping thrust, referred to as the Contact fault system, separates the two subduction complexes. Sediments of the Orca Group have been generally metamorphosed to prehnite-pumpellyite to low-grade greenschist facies.

Sedimentary rocks, in part younger than the Orca Group, crop out in the southeastern parci of the study 
area. These rocks, consisting of the Stillwater, Kulthieth, Tokun, Poul Creek, Redwood, and Yakataga Formations, represent sediment deposition in a continental margin basin in which marine regression and transgression took place during the middle Eocene and into the late Miocene (Plafker, 1971; Winkler and Plafker, 1981).

Two periods of anatectic plutonism closely followed accretion and deformation of the Valdez and Orca Groups. Plutonic bodies developed during both events have intruded both the Valdez Group and the Orca Group. The earliest event has been dated by KAr methods as $50-53$ m.y. in age (Plafker and Lanphere, 1974; Nelson, Dumoulin, and Miller, 1984). Biotite granite, hornblende-biotite granite, granodiorite, and tonalite produced during this episode make up a portion of the Sanak-Baranof plutonic belt, which rims the Gulf of Alaska (Hudson and others, 1979). Felsic through mafic plutons, ranging in age from 34 to $37 \mathrm{m.y}$., form the younger intrusive suite (Lanphere, 1966).

\section{METHODS}

Heavy-mineral-concentrate samples of sediment were collected at 2,013 sites using a 14-in.-diameter gold pan. Samples were taken from first- or secondorder drainages at an approximate density of one site per $4 \mathrm{sq} \mathrm{mi}$. In areas of extensive glacial cover, concentrates were collected from active medial or lateral moraines. Glaciofluvial outwash was also sampled from below the toe of many of the smaller valley glaciers. At least five grab samples were collected and composited at each site along a $30-\mathrm{ft}$ stretch of the active stream channel or moraine, using a polyethylene or aluminum scoop. Commonly $3-4 \mathrm{~kg}$ of composited sediment were collected to yield the desired $30-60 \mathrm{~g}$ of concentrate.

The samples were air dried in the laboratory and the highly magnetic material (magnetite, ilmenite) was removed with an electromagnet. Lightweight material was separated by flotation in bromoform (specific gravity 2.86 ), and the resulting heavy-mineral fraction was then separated into nonmagnetic and magnetic fractions using a Frantz Isodynamic Separator ${ }^{P}$ at a setting of 0.6 ampere, and slope settings of $15^{\circ}$ forward and $15^{\circ}$ side.

A split of the nonmagnetic fraction was analyzed semiquantitatively for 31 elements using an optical emission spectrograph, according to the method outlined by Grimes and Marranzino (1968). The semiquantitative spectrographic values are reported as the approximate geometric midpoints (1.0, 0.7, 0.5, $0.3,0.2,0.15$, or appropriate powers of 10) of ranges whose respective boundaries are $1.2,0.83,0.56,0.38$, $0.26,0.18,0.12$ (or appropriate multiples). The precision of the analytical method is approximately plus or minus one reporting interval at the 83 percent confidence level and plus or minus two reporting

${ }^{l_{A n y}}$ use of trade names in this report is for descriptive purposes only and does not imply endorsement by the U.S. Geological Survey. intervals at the 96 percent confidence level (Motooka and Grimes, 1976).

A second split of the nonmagnetic fraction was taken for microscopic examination of all samples. Thirty-four samples having microscopically visible man-made contamination were deleted from the original data base of 2,013 samples.

\section{STATISTICAL SUMMARY}

We have used the "boxplot" (Tukey, 1977) to conveniently show the range of observed concentrations for the elements reported (fig. 1). For many of the boxplots, the maximum, the 99th percentile, the 95 th percentile, the upper quartile, the median, the lower quartile, and the minimum value are shown. Some of the boxplots are abbreviated because (1) in many of the samples the concentrations of some elements are lower than their determination limits and (2) in some of the samples the concentrations of some elements are greater than their determination limits. The presence of qualified values for a particular element are indicated by an arrow at either the top or the bottom of the boxplot to show either greater than or less than a given determination limit.

Histograms of most of the elements are shown in figure 2; elements that have highly censored data are not shown. The spectrographic intervals are used as class widths. The histograms conveniently show the range of the data, the modes, and the general form of the density distribution. The number of samples below the determination limit is indicated by " $\mathrm{n}$ "' at the left of the histograms, whereas the number of samples that exceed the determination limit of measurement is indicated by " $n$ "' at the right of the histograms.

Table 1 presents univariate statistics for those elements that have detection ratios greater than \$.6. Detection ratios, which are the number of uncensored values divided by the total number of samples analyzed for a given element, describe the degree to which the data were censored (Miesch, 1976). Many of the distributions were singly censored, such that some values were either above or below the determination limit for the analytical standards used.

The geometric mean and geometric deviation (the antilogs of the mean log and log standard deviation, respectively) shown on table 1 were calculated using the U.S. Geological Survey's STATPAC program for Fisher-K statistics (Miesch and VanTrump, 1977). This program allows the mean log and log variance to be determined using Cohen's (1959) method for the maximum likelihood estimate for normal and singly censored distributions. For log normal data, 95 percent of all values fall within an expected, range from geometric mean/(geometric deviation) ${ }^{2}$ to geometric mean $\times$ (geometric deviation) ${ }^{2}$.

Thresholds for the anomalous populations of selected elements in the concentrate samples are shown in table 2. Because the concentrate samples were derived from a variety of rock types, we arbitrarily chose as anomalous those concentrations that approximate as closely as possible the upper 5 percent of the data. For some elements, the regional threshold was adjusted up or down from the 95th 
percentile to accommodate distinct breaks in the distribution of the data or highly censored data.

$R$-mode factor analysis with varimax rotation was used to identify groups of intercorrelated variables in the heavy-mineral-concentrate data base. This analysis places similarly behaving experimental variables (elements) into groups termed "factors." Specific types of ore deposits may contain an anomalous geochemical signature characterized by a distinct suite of trace elements. Therefore, certain factors might be useful in defining the mineral deposit types within the Chugach National Forest.

We used the RRMODE factor analysis program in the U.S. Geological Survey's STATPAC system (Miesch and VanTrump, 1977). R-mode factor analysis was run on log-transformed data for 22 elements; $\mathrm{Au}, \mathrm{Bi}, \mathrm{Cd}$, $\mathrm{Mo}, \mathrm{Sb}, \mathrm{Sn}$, and Th were all highly censored so they were not included in the analysis. In the next section of this report, factor loadings are used to depict the influence of each factor on a variable and may be interpreted similarly to correlation coefficients. The described factor scores for each sample on each factor are used to measure the "effect" of that factor on each individual sample. A high score for a given sample indicates a strong enrichment in those elements with the more positive loadings and (or) a strong depletion in those elements with the more negative loadings. The reader is referred to Davis (1973), Johnston (1980), and Joreskog and others (1976) for more information on the theory and technique of factor analysis.

\section{DISTRIBUTION OF ANOMALOUS ELEMENT SUITES}

Factor analysis of the original concentrate data indicated that some of the variance is analytical. The most significant factor, accounting for slightly more than 21 percent of the total variance, was characterized by a $\mathrm{Mg}-\mathrm{Mn}-\mathrm{Cr}-\mathrm{Sc}-\mathrm{V}-\mathrm{Ca}$ association. Interpretation of the corresponding scores showed that this factor contains much of the analytical variance. Because the geochemical sampling program for this study extended over a number of years, the spectrographic data represent the combined efforts of various analysts working with different spectrometers. Highest scores onto this first factor all represent samples run by one analyst, whereas the lowest scores reflect samples analyzed by a different analyst at another time. No definable spatial or geologic patterns existed for the scores.

To eliminate much of the analytical variance from the data base, a file of factor residuals was computed, excluding the first factor. The residuals are actually not true residuals, that is, they do not average zero, but may be defined as the average of the variable means (Al Miesch, oral commun., 1985). The six-factor R-mode factor loadings and cumulative variances for a new model, run on the residual data, are shown in table 3.

\section{Distribution of the $\mathrm{Fe}-\mathrm{Co}-\mathrm{Cu}-\mathrm{Ni}$ suite}

The first factor in the new model, explaining 22 percent of the total variance, defines samples with anomalous concentrations of $\mathrm{Fe}, \mathrm{Co}, \mathrm{Cu}$, and (or) $\mathrm{Ni}$. Apparently this suite of trace metals is representative of heavy-mineral-concentrate samples having the greatest abundance of sulfide minerals, particularly pyrite, pyrrhotite, and chalcopyrite.

Samples with the highest factor 1 scores from the western half of the Chugach National Forest cluster to the northeast of Coghill Lake (1A), from Harriman Fiord southwest to the Upper Carmen River (1B), along the Contact fault from near Ellsworth Glacier to Kings Bay (1C), and along the western side of Excelsior Glacier (1D). Samples from all of these localities also contain visible arsenopyrite, but rarely contain any $A u$ despite the fact that many of these areas are adjacent to Au-bearing regiors (see "Distribution of precious metals" section).

These anomalous samples all tend to be derived from watersheds underlain by turbidite sequences of the Valdez and Orca Groups. Although some of the sulfide minerals could have been derived from disseminations within the metasedimentary rocks themselves, we believe that most of the sulfide minerals have been weathered from widespread, small, discordant quartz veins mainly localized in shear zones. In area IA, Jansons and others (1984) rsported the presence of small quartz veins containing visible pyrite, arsenopyrite, and galena within a shear zone between an intrusive body and metasedimentar" rocks near Dartmouth Glacier. In area 1B, Jansons and others (1984) discovered quartz veins containing pyrite, arsenopyrite, chalcopyrite, and galena crosscutting the Valdez Group sediments. In area 1C, quartz-calcite veins cutting felsic dikes near Wolverine Glacier and in the headwaters of th- Kings River, both just to the west of the Contact fault, carry pyrite, pyrrhotite, chalcopyrite, and arseropyrite (Jansons and others, 1984). Also in area 1C, a sample of glacial outwash sediment collected at the toe of Falling Glacier to the east of the Contact fault (site 0478C, Goldfarb and others, 1984) contains mcre than 2 percent $A s$ and also carries detectable $A u$, whereas most other samples with high factor 1 scores do not carry detectable Au.

High factor 1 scores also characterize an area to the south of the Miners River (IE), which is underlain by the Orca Group. Concentrate samples from this locality contain abundant pyrite, arsenopyrite, chalcopyrite, barite, galena, and sphalerite. These minerals were derived from brecciated base-metalbearing quartz veins, pods of massive sulfide, and disseminated sulfides in the Orca Group occurring throughout this region. Geochemical data for the base-metal-bearing quartz veins are as follow's: $\mathrm{Pb}$, $20,000 \mathrm{ppm} ; \mathrm{Zn}$, over 25,000 ppm; $\mathrm{Cu}$, as nuch as 20,000 ppm; Ba, as much as 5,000 ppm; As, 4,500 ppm; Ag, 150 ppm; Sb, 100 ppm (R. J. Goldfarb, unpub. data). Gold was rarely detected at the $0.05 \mathrm{ppm}$ lower limit of determination in most of these samples.

The massive sulfide pods and the coarse quartzsulfide brecciation in area IE are possibly indicative of syngenetic volcanogenic sulfide mineralization and later remobilization of sulfide minerals into shear zones cutting slate and graywacke in the Orca Group. This area does contain some small greenstone bodies, which supports the occurrence of localized submarine volcanism. However, the presence of abundant galena and barite in the veins suggests a major difference 
between these occurrences and the $\mathrm{Fe}-\mathrm{Cu}-\mathrm{Zn}$ massive sulfide deposits seen elsewhere in the Chugach National Forest (Nelson, Miller, and others, 1984). Area $I E$ is also near the Eocene(?) Cedar Bay Granite (Tysdal and Case, 1979), which is cut by mineralized base-metal veins at the head of Cedar Bay. More detailed study of the polymetallic occurrences is required before the relationship of the intrusive activity to the sulfide mineralization is clearly understood.

Samples having high scores for the $\mathrm{Fe}-\mathrm{Co}-\mathrm{Cu}-\mathrm{Ni}$ association in the eastern half of the Chugach National Forest occur in the vicinity of Brown Basin (IF), Woodworth Glacier (1G), and Schwan Glacier (1G), along the western shore of the Copper River (1G), in the headwaters of the Rude River drainage system (IG), and along Power and Ibeck Creeks (1G). Concentrate samples from these areas contain abundant $\mathrm{Fe}$ and $\mathrm{Cu}$ sulfides. This part of the Chugach Mountains is dominantly underlain by tholeiitic basalt of both the Valdez and Orca Groups, and interbedded metasedimentary units. The majority of the sulfides are thought to have been derived from quartz veins within shear zones cutting both metavolcanic and metasedimentary units. The relative inaccessibility of this part of the Chugach Mountains has historically hampered mineral exploration, and thus there are relatively few recorded prospects or mines within this part of the Chugach National Forest. However, microscopic examination of polished thin sections from discordant quartz veins throughout this region consistently shows pyrrhotite, pyrite, chalcopyrite, sphalerite, and $\mathrm{Fe}$ and $\mathrm{Cu}$ oxides disseminated throughout the quartz.

Samples from areas $I F$ and $I G$ often contain other elements in anomalous concentrations in addition to $\mathrm{Fe}, \mathrm{Cu}, \mathrm{Co}$, and (or) $\mathrm{Ni}$. Many concentrate samples from the Schwan Glacier moraines contain anomalous amounts of $\mathrm{Au}$. This contrasts with other areas of the national forest where Au-bearing samples are often found adjacent to, but not spatially associated with, samples enriched in $\mathrm{Fe}, \mathrm{Co}, \mathrm{Cu}$, and (or) $\mathrm{Ni}$. Anomalous amounts of As are found in samples from Ibeck Creek, anomalous $\mathrm{Pb}$ is present in samples from Power Creek, and anomalous $\mathrm{As}$ and $\mathrm{Pb}$ are found in samples from the headwaters of the east fork of the Rude River. These three areas are all underlain by the Orca Group. Galena and arsenopyrite in quartz veins were observed to cut the Orca Group. Lead and As were rarely detected in samples from drainages underlain by the Valdez Group to the immediate north. These data suggest that the sulfide mineralogy changes slightly across the Contact fault.

Samples with high factor 1 scores are also found in the younger Tertiary sediments within the southeastern corner of the national forest $(\mathrm{IH})$. Barite, sphalerite, and sedimentary pyrite (Richard Tripp, oral commun., 1983) are noted in many of these samples. Most of the anomalous samples are being derived from the Tertiary Poul Creek and Tokun Formations, although a few apparently are being weathered from the volcanic rocks of the Orca Group just west of the Ragged Mountain fault. The sulfideand sulfate-bearing minerals are believed to have been released from glauconitic horizons within the marine shale and (or) from mafic flows and dikes in the upper part of the Poul Creek Formation (Pickthorn and others, 1985).

\section{Distribution of the La-Nb-Y-Zr-(-Cr)-(-Mg) suite}

Factor 2, accounting for about 15 percent of the total variance in the data, is distinguished by relatively positive loadings for REE (rare-sarth elements; $\mathrm{La}, \mathrm{Nb}, \mathrm{Y}$, and $\mathrm{Zr}$ ) and negative loadincs for $\mathrm{Cr}$ and $\mathrm{Mg}$. High factor 2 scores characterize móst of the igneous bodies intruding both the Valdez and Orca Groups, including the Oligocene granite and granodiorite bodies at Eshamy Bay (2A), Port Nellie Juan (2B), Culross Island (2C), and Esther Island (2D), and the Eocene granite and granodiorite bodies near Cedar Bay (2E) and Sheep Bay (2F). High concentrations of REE scattered to the southeart of Port Valdez and in the Cleave Creek Glacier area may reflect localized intrusive activity. In the latter region, Winkler and others (1981) have mappsd a number of small felsic dikes.

To the east of the Copper River (2G), relative REE enrichments and $\mathrm{Cr}-\mathrm{Mg}$ depletions characterize concentrate samples derived from valleys underlain by the paragneiss of the "Chugach metamorphic comolex" (Hudson and Plafker, 1982). Granitic lenses, dikes, and sills are common throughout this highly metamorphosed section of the Valdez Group sedimentary rocks.

High factor 2 scores also charactorize concentrate samples from the Bering River region $(2 \mathrm{H})$, underlain by the Tertiary Stillwater, Kultrieth, Tokun, and Poul Creek Formations. Howsver, concentrate samples derived from the younger Yakataga Formation, underlying most of Kayak Island, show no such REE enrichment. The relative abunc'ance of $\mathrm{La}, \mathrm{Nb}, \mathrm{Y}$, and $\mathrm{Zr}$ in the four former formations is likely due to the high proportion of accessory minerals, such as apatite and zircon included within these units. Richard Tripp (unpub. data) has observed a high proportion of zircon within the samples showing high REE values. The Yakataga Formation is predominantly ice-rafted debris believed to have been derived during pronounced uplift along the Gulf of Alaska (Plafker, 1974); thus, concentrate sarnples weathered from this formation would be expected to have REE contents similar to those of the older Orca Group rocks.

Montague Island (2I), which is underlain by lowgrade metasedimentary rocks of the Orca Group, represents the only sub-amphibolite-grade section of metasedimentary rocks in the Chugach National Forest that contains anomalous REE concentrations. This might indicate a distinct provenance for the Mont ague Island rocks relative to the remainder of the Orca Group. Alternatively, Dumoulin (1984) has hypothesized a gradually evolving source for both the Valdez and Orca Groups. Dumoulin reported that there may be no real difference between the two accreted packages and showed statistically significant mineralogical trends eastward across the southern Kenai Peninsula indicative of a shift from a volcanic 
source area to the unroofing of a plutonic system. Montague Island perhaps could represent the final accreted part of this magmatic arc province.

Low factor 2 scores define the greenstone belt of the Orca Group within the central part of Prince William Sound (2J). Low REE and high $\mathrm{Mg}-\mathrm{Cr}$ concentrations characterize heavy-mineralconcentrate samples weathered from pillow basalt, sheeted dikes, gabbro, or ultramafic rocks on Evans, Erlington, and eastern Bainbridge Islands, Knight Island, Glacier Island, at Ellamar, and south of Port Fidalgo. Low factor 2 scores on Glacier Island continue across to the adjacent mainland where we have observed unmapped greenstone north of Long Bay.

The upper part of Resurrection Peninsula (2K), which is underlain by pillow basalt, sheeted dikes, gabbro, and ultramafic rocks of the Valdez Group, shows the same low REE and high $\mathrm{Mg}-\mathrm{Cr}$ geochemical signature as the previously discussed greenstone belt of the Orca Group in area 2J. To the east of Resurrection Peninsula and surrounding Whidbey Bay (2L), three concentrate samples (B50243, B50244, and B50562; Goldfarb and others, 1984) are also enriched in $\mathrm{Cr}$ and $\mathrm{Mg}$ and are markedly depleted in $\mathrm{Zr}$. Perhaps this is indicative of other small mafic volcanic bodies within the turbidites to the east of Day Harbor.

The various volcanic rock types of Knight Island are hosts for a number of small Cyprus-type $\mathrm{Fe}-\mathrm{Cu}-\mathrm{Zn}$ massive sulfide deposits (Koski and others, 1985). Numerous concentrate samples containing abundant chalcopyrite and $\mathrm{Fe}$ sulfides (Goldfarb and Tripp, 1985), mainly derived from the sheeted dikes underlying the eastern half of the island, delineate areas of highest favorability for the occurrence of massive sulfide deposits. However, despite the large amount of $\mathrm{Fe}$ - and $\mathrm{Cu}$-bearing sulfides in the samples, the low REE and high $\mathrm{Mg}-\mathrm{Cr}$ concentrations geochemically distinguish these samples from the other sulfide-rich samples defined by factor 1 .

Examination of the distribution of chalcopyrite (Goldfarb and Tripp, 1985) and the distribution of only $\mathrm{Cu}$ concentrations (Goldfarb, unpub. data) indicates that Knight Island is the only part of the Prince William Sound greenstone belt that has substantial geochemical favorability for Cyprus-type (volcanichosted) massive sulfide deposits. Anomalous amounts of $\mathrm{Cu}$ in concentrate samples were not detected on Resurrection Peninsula, on Evans, Erlington, and eastern Bainbridge Islands, or on Glacier Island. Some anomalous amounts of $\mathrm{Cu}$ (and visible chalcopyrite) in concentrate samples were observed to cluster in parts of the Ellamar and Port Fidalgo areas, but we found these samples to have been derived from watersheds predominantly underlain by metasedimentary rocks and not greenstone. Moffit and Fellows (1950) noted that indeed most of the $\mathrm{Cu}$ occurrences are hosted by sedimentary rocks in the Ellamar and Port Fidalgo areas. The samples from both areas with lowest factor 2 scores, and thus derived from the interbedded greenstone bodies, all lack chalcopyrite, supporting Moffit's and Fellows' observation that economic Cyprus-type mineral occurrences are not present.

The mafic volcanic rocks forming the high peaks of the Chugach Mountains across the Cordova $1^{0} \times 3^{0}$ quadrangle and those between the Rude River and Scott Glacier to the northeast of the town of Cordova both lack relatively low factor 2 scores. The greenstone bodies within these regiors yield concentrate samples having low to moderate $\mathrm{Cr}$ contents, low Mg contents, and moderate to high REE contents. This geochemical contrast with tho Prince William Sound greenstone belt is suggestive of at least two distinct episodes of sea-floor volcanism coeval with sedimentation.

\section{Distribution of the $\mathrm{Ca}-(-\mathrm{Zn})$ suite}

Factor 3, explaining about 8 percent of the total variance in the data, defines samples having anomalous concentrations of $\mathrm{Ca}$ or $\mathrm{Zn}$. Samples with the highest factor 3 scores are scattered throughout all lithologies of the Chugach National Forest, excluding the youngest Tertiary sediments in the southeast. corner. Samples having high factor 3 scores and consequently high $\mathrm{Ca}$ concentrations, are scattered over much of Knight Island, to the southeast of the Sargent Icefield, in the Billings Glacier region north of Passage Canal, in the vicinity of the Dead Creek-Brow'n Basin watersheds, to the southeast of Cordova Peak, and in the vicinity of McPherson Glacier. For the most part though, high factor 3 scores probably define orcasional apatite-rich beds within the Valdez and Orce Groups. Richard Tripp (unpub. data) has noted black anatite in many of the samples with $\mathrm{Ca}$ concentrations of at least 10 percent.

Low factor 3 scores indicate anomalous amounts of $\mathrm{Zn}$, which has a high negative loading, and (or) low $\mathrm{Ca}$ in the concentrate samples. The lowest scores are derived from samples collected in streams draining all the younger Tertiary sedimentary formations in the southeast corner of the Chugach National Forest (3A). Sphalerite and barite were identified in samples from watersheds underlain by the Poul Creek and Yakataga Formations (Goldfarb and others, 1985). Sphalerite was not observed in samples from the Stillwater, Kulthieth, and Tokun Formations and no anomalous amounts of $\mathrm{Zn}$ were detected. The low scores associated with these latter formations only reflect the extremely low $\mathrm{Ca}$ concentrations relative to the regionally more extensive metasedimentary sequences of the Valdez and Orca Groups.

The west side of Latouche Island (3B), th? region south of the Miners River (3C), the western shore of Port Wells (3D), and an area northwest of Twontymile Glacier (3E) all contain anomalous amounts of $\mathrm{Zn}$ in concentrate samples in which sphalerite was identified. The Besshi-type $\mathrm{Cu}$ occurrence at the Beatson mine on Latouche Island was historically the second largest $\mathrm{Cu}$ producer in Alaska. Anomalous amounts of $\mathrm{Zn}$ in drainages along the east sic's of the island obviously reflects other small sedimert-hosted $\mathrm{Fe}, \mathrm{Cu}$, and $\mathrm{Zn}$ sulfide occurrences. Sphalerite south of the Miners River is being weathered out of the previously discussed quartz veins and massive sulfide pods. Gold-bearing quartz veins containing varying amounts of sulfide minerals, known to exist in Port Wells and near Twentymile Glacier, are the sisspected sources for the $\mathrm{Zn}$ anomalies in these areas. 
Low factor 3 scores cluster over much of Bainbridge Island (3F). Sulfides were not noted in the concentrate samples and yet many contained anomalous amounts of $\mathrm{Zn}$, as well as $\mathrm{Fe}, \mathrm{Mn}, \mathrm{Cu}, \mathrm{Cr}$, and $\mathrm{Ni}$. The source of these anomalies is presently unknown.

Anomalously low factor 3 scores once again distinguish the Orca Group on Montague Island (3G) from the rest of the Orca Group within the Chugach National Forest. Some of the scores may be related to very low $\mathrm{Ca}$ concentrations, whereas others definitely identify $\mathrm{Zn}$ enrichments. Sphalerite, corresponding with the enrichments, has been identified in concentrates taken from streams on both sides of the Patton Bay fault.

A striking negative $\mathrm{Ca}$ anomaly occurs south of Port Fidalgo and west of the Sheep Bay pluton $(3 \mathrm{H})$ in Orca Group metasedimentary rocks. Area $3 \mathrm{H}$ and Montague Island both yield concentrate samples having strikingly lower $\mathrm{Ca}$ contents than the other areas underlain by Orca Group rocks. However, unlike Montague Island, there is no REE enrichment here.

Low factor 3 scores are associated with the area underlain by the Cedar Bay Granite (3I) and an area north of Esther Passage (3J). Both seem to be related to low $\mathrm{Ca}$ values for heavy-mineral concentrates. However, one sample (0665C, Goldfarb and others, 1984) from the latter contains anomalous amounts of $\mathrm{Zn}$ and abundant pyrite, sphalerite, and chalcopyrite. The sulfides are believed to have been derived from quartz veins within the surrounding Golden gold district.

\section{Distribution of the $\mathrm{Ba}-\mathrm{Sr} \pm \mathrm{Be}, \mathrm{Zn}$ suite}

Factor 4, explaining about 7 percent of the total variance in the data, defines samples having anomalous concentrations of $\mathrm{Ba}$ and $\mathrm{Sr}( \pm \mathrm{Be}$ and $\mathrm{Zn}$ ) and high factor 4 scores delineate areas containing widespread barite. The common occurrence of barite and sphalerite together in certain mineral deposits accounts for the weakly significant positive $\mathrm{Zn}$ loading. Thus, as was the case for the lowest factor 3 scores, the highest factor 4 scores delineate an area of barite and sphalerite in the younger Tertiary sedimentary rocks (4A), an area of sulfide mineralization south of Miners River (4B), and the Twentymile Glacier-Girdwood gold district lodes (4C). High factor 4 scores also delineate a region of anomalous $\mathrm{Ba}$ extending from the eastern half of Kenai Lake to the east of Ptarmigan Lake (4D). Microscopic observation of the concentrate samples from area $4 D$ shows barite, pyrite, and occasional sphalerite, chalcopyrite, and arsenopyrite. Despite the general lack of $A u$ in all but a few of these samples, we believe the sulfides were eroded from epigenetic quartz lodes, which are widespread throughout this part of the Kenai Peninsula.

High factor 4 scores also characterize much of the Orca Group from Sheep Bay east to the Copper River and the eastern half of Hinchinbrook Island (4E). The most anomalous $\mathrm{Ba}$ values seem to be associated with the metavolcanic rocks northeast of Cordova and on Hinchinbrook Island. The Ba anomalies do not cross the Gravina fault, suggesting a geochemical difference from the greenstone bodies hosted by the Valdez Group to the north. Only a few samples from Montague Island yielded anomalous factor 4 scores, due to the low Ca values of most samples from the island causing them to be best explained by low factor 3 scores. However, interpretation of solely the $\mathrm{Ba}$ data shows that the $\mathrm{Ba}$ anomalies continue down the entire length of Montague Island (3G). Goldfarb and others (1985) defined a belt of barite, chalcopyrite, and pyrite ( \pm sphalerite), based on microscopic examination of the concentrate samples, extending from the southern tip of Montague Island to the northeast for about $100 \mathrm{mi}$ into the lower elevations of the Rude River watershed. It is presently unknown whether the sulfides and sulfates are being weathered from quartz veins, massive sulfide pods, or syng onetic disseminations.

High factor 4 scores also are shown by semples from an area just to the east of the Johnston? Bay fault from Johnstone Bay north to the southern tip of Chenega Island (4F) and between Culross Passage and Cochrane Bay (4G). For the most part, the semples contain anomalous amounts of $\mathrm{Sr}$ and $\mathrm{Be}$ and lack any ore minerals. Some of the most anomalous semples also contain very high $\mathrm{Nb}$ concentrations and the "efore may represent geochemical signatures of small felsic dikes or plutons. Area $4 \mathrm{G}$ does in fact adjoin a small intrusive body.

\section{Distribution of the B-Be suite}

Factor 5, explaining about 5 percent of the total variance, defines samples having anornalous concentrations of $\mathrm{B}$ and $\mathrm{Be}$. High factor 5 scores characterize samples from most of the southern half of the Kenai Peninsula $(5 \mathrm{~A})$ and a 25-mi-long telt of samples from Twentymile Glacier northeast to Barry Glacier (5B). These anomalous samples may just represent weathering products from the more clay-rich units of the Valdez Group. High factor 5 scores also characterize clusters of samples enriched in $\mathrm{B}$ and $\mathrm{Be}$ along the western shore of Port Wells (5C) and surrounding Eshamy Bay (5D). These anomalous samples might be products of the same differential weathering or could represent enrichments from igneous bodies exposed in adjacent watersheds. Samples from many of the medial moraines on $\mathrm{fart}$ of Columbia Glacier, just west of Divider Mountain (5E), also show high factor 5 scores and high concentrations of $\mathrm{B}$ and $\mathrm{Be}$, which might be related to the abundant calcite veining observed within the supraglacial material.

The only cluster of high factor 5 scores in the eastern half of the Chugach National Forest is in the Shepard Glacier-McKinley Peak region (5F). Semples containing elevated $B$ and $B e$ concentrations from an unknown source were collected from watesheds overlying igneous, metasedimentary, and metavolcanic rocks. Elevated $\mathrm{B}$ and $\mathrm{Be}$ concentrations are also scattered in the amphibolite-grade rocks east of the Copper River where felsic segregations and tourmaline are common in the more schistose rocks. 


\section{Distribution of precious metals}

Factor 6, explaining about 5 percent of the total variance in the data, defines samples having anomalous concentrations of $\mathrm{Ag}, \mathrm{As}$, and $\mathrm{Pb}$. These samples largely delineate many of the regions containing widespread placer gold. However, since arsenopyrite and galena are not universally present in the gold source lodes, anomalous factor 6 scores do not present the most accurate picture of placer gold distribution.

Gold was detected by emission spectroscopy and (or) observed microscopically in 223 of the 1,979 heavy-mineral-concentrate samples. Silver was the only other trace metal consistently enriched in the Aubearing samples. However, occasional samples containing anomalous $\mathrm{Ag}$ but no $\mathrm{Au}$ were found scattered between Au-rich samples. In an effort to quantify the $\mathrm{Ag}-\mathrm{Au}$ geochemical signature and thus identify areas of highest geochemical favorability for placer gold and source lodes, we used a simple ranking procedure described in Leach and Goldfarb (in press) and Goldfarb and others (1983). This program ranks chemical data for each element based on its concentration. The smallest concentration for each variable has a rank of "l" and the largest has a rank of " $n$ ", where " $n$ " equals the total number of samples. When tied observations occur, they are assigned the mean of the ranks they would have had if they had been distinct. The ranks for each sample are then summed for a suite of elements believed to be related to a particular mineral deposit type. The net effect of this procedure is to transform any number of separate element distributions into a single unitless distribution that represents a total metal signature for the summed elements.

Clusters of high Ag-Au rank sums determined by the previously mentioned procedure describe favorable placer gold localities throughout much of the area underlain by the Valdez Group. Goldfarb and others (1987) discuss the affinity of Au for the mid-grade greenschist facies metasedimentary rocks of the Valdez Group. The bulk of the placer gold is believed to have been derived from epigenetic Au-bearing quartz veins emplaced along shear zones, faults, and joints. Anomalous Au signatures within the Valdez Group are found over much of the northern Kenai Peninsula (6A), in the vicinity of Kenai Lake (6B), east of Turnagain Arm (6C), along the western shore of Port Wells (6D), north of Harriman Fiord (6E), east of Port Wells (6F), north of Miners River (6G), in the Cleave Creek Glacier region $(6 \mathrm{H})$, near the mouth of the Bremner River (6I), in the vicinity of Meteorite Mountain and Brown Basin (6J), and around Schwan and Woodworth Glaciers (6K).

Area $6 \mathrm{~K}$ possibly hosts a genetically different bedrock source for the Au than the other areas. Goldand Ag-rich samples in this area are derived from greenstone bodies within the Valdez Group. Epigenetic veins crosscut these metavolcanic rocks, but we have only observed pyrrhotite, pyrite, chalcopyrite, and sphalerite in the veins. Small amounts of $A u$ and $A g$ were recovered from many of the $\mathrm{Fe}-\mathrm{Cu}-\mathrm{Zn}$ massive sulfide deposits elsewhere in the Chugach National Forest (Moffit and Fellows, 1950). At the Ellamar mine, $A u$ is often finely disseminated in massive chalcopyrite (Don Grybeck, written commun., 1985).
Therefore, the $A u$ in area $6 K$ could possibly be weathered from as yet undiscovered massive sulfide bodies. The consistent lack of anomalous $A s$ in the placer samples further contrasts this area from those where the Au-bearing samples are being derived from veins within metasedimentary host beds.

Anomalous Ag-Au rank sums also characterize four areas underlain by Orca Group rocks. The one sizable clustering of samples lies south of the Sargent Icefield (6L). This is the only sizable area of mediumgrade greenschist facies rocks within the Orca Group (Goldfarb and others, 1987). The Au is belisved to have been eroded from both exposed quartz veins and those concealed by the icefield. Gold-bearing samples to the east of the town of Cordova (6M) in the McKinley Peak district and to the north of the Sargent Icefield $(6 \mathrm{~N})$ are found in the vicinity of small intrusive bodies. Several samples with anomalous precious-metal values were also collected from drainages above the Beatson copper mine on Latouche Island (60), where the sulfide ore is known to have yielded subordinate $A u$ as a milling byproduct (Moffit and Fellows, 1950).

\section{Distribution of other trace elements}

The $\mathrm{Bi}, \mathrm{Cd}, \mathrm{Sb}, \mathrm{Mo}, \mathrm{Sn}, \mathrm{Th}$, and $\mathrm{W}$ data ars either too highly censored for detailed statistical interpretation and (or) lack significant correlation with any other minor or trace element data. Yet the common relationship of these elements to many mineral deposits warrants the need for a clear understanding of their distribution in the heavymineral-concentrate samples.

Anomalous amounts of $\mathrm{Bi}$ are associated with several ore-mineral systems within the Chugach National Forest. As much as 300 ppm are comnon for concentrate samples draining the base-metal-rich occurrences discussed previously to the so'sth of the Miners River (IE). These samples are gimnerally distinguished by anomalous amounts of $\mathrm{Fe}, \mathrm{Ag}, \mathrm{As}, \mathrm{Ba}$, $\mathrm{Bi}, \mathrm{Co}, \mathrm{Cu}, \mathrm{Pb}$, and $\mathrm{Zn}$. In the Meteorite MountainBrown Basin region (6J) and around Cleave Creek Glacier $(6 \mathrm{H})$, Bi concentrations between $70 \mathrm{ppm}$ and $300 \mathrm{ppm}$ are found associated with $\mathrm{Ag}, \mathrm{As}, \mathrm{Au}, \mathrm{Co}, \mathrm{Cu}$, $\mathrm{Pb}$, and $\mathrm{W}$ enrichments. High $\mathrm{Bi}$ concentrations between $20 \mathrm{ppm}$ and $50 \mathrm{ppm}$ accompany anomalous amounts of $\mathrm{Fe}, \mathrm{Ag}, \mathrm{As}, \mathrm{Cu}, \mathrm{Ni}$, and $\mathrm{Pb}$ along ths entire length of the east fork of the Rude River (1G). Because of its chalcophile tendency, $\mathrm{Bi}$ commonly occurs in trace quantities in various common sulfide minerals, most notably galena (Kupcik and others, 1972). The areas just discussed represent localities within the Chugach National Forest where concentrates are the most enriched in galena (Goldfarb and others, 1985); therefore, we conclude that the anomalous $\mathrm{Bi}$ is found within the galena.

Bismuth will also tend to accumulate in residual melts during normal magmatic differentiation processes. A scattering of samples containing only anomalous amounts of $\mathrm{Bi}$ to the east of the Copper River, especially along the north side of Miles Glacier, may reflect the common occurrence of pecamatitic zones along pluton-schist contacts and within dikes in the "Chugach metamorphic complex" (2G) (Huc'son and Plafker, 1982). 
Two of the highest concentrations of $\mathrm{Bi}$ were found in samples collected along the north side of Falling Glacier ( $6 \mathrm{~N})$ in Kings Bay $(\mathrm{Bi}=500 \mathrm{ppm}$; sample 0477, Goldfarb and others, 1984) and on the east side of Billings Glacier along Passage Canal (Bi=l,000 ppm; sample 0636, Goldfarb and others, 1984). Sample 0477 also contains very high $A s, C u, S n$, and $W$ concentrations and visible $A u$, whereas sample 0636 is particularly enriched in $\mathrm{Mn}, \mathrm{As}, \mathrm{Cr}$, and $\mathrm{W}$. Both samples are derived from watersheds partially underlain by intrusive bodies, and the existence of contact metasomatic mineralization can not be ruled out at either locality.

Cadmium was only detected in 18 heavy-mineralconcentrate samples. Most of these samples are from drainages underlain by the Tertiary Poul Creek and Yakataga Formations in the southeast corner of the Chugach National Forest (3A); a few are from watersheds south of Miners River (IE). All the samples also contain highly anomalous amounts of $\mathrm{Zn}$, and coupled with the microscopic confirmation of abundant sphalerite, we conclude that the $\mathrm{Cd}$ is substituted within the sphalerite crystal structure.

Antimony was detected in 31 concentrate samples from the Chugach National Forest. Many of these are scattered around the Kenai Peninsula (6A and 6B), western Port Wells (6D), or the Coghill Lake region $(6 \mathrm{~F})$. The $\mathrm{Sb}$ in all four of these areas is believed to have been derived from Au-bearing quartz veins within the Valdez Group because the samples are also anomalous in $\mathrm{Fe}, \mathrm{Ag}, \mathrm{As}, \mathrm{Au}, \mathrm{Cu}$, and $\mathrm{Pb}$. We have identified rare tetrahedrite and stibnite in some of the lodes hosted in the Valdez Group and believe the $S b$ to exist in either form although neither mineral was identified in the heavy-mineral-concentrate samples. $A$ very well defined belt (6C) of anomalous $S b$, associated with $\mathrm{Fe}-\mathrm{Ag}-\mathrm{As}-\mathrm{Au}-\mathrm{Co}-\mathrm{Cu}-\mathrm{Ni}-\mathrm{Pb}-\mathrm{Zn}$ enrichment, extends from Boggs Peak south to Trail Glacier. Stibnite was identified in placer samples draining off Begich and Curpathian Peaks. Quartz veins along this north-south belt may carry exceptionally high percentages of stibnite. Finally, a few $\mathrm{Sb}$ anomalies are associated with the Au-rich placers north of Miners River and the base-metal-rich placers south of Miners River.

The distribution of anomalous amounts of $\mathrm{Mo}$ indicates a low geochemical favorability for any Morich resources within the Chugach-Kenai Mountains. Enrichments of Mo in samples draining the younger Tertiary sediments east of Ragged Mountain appear to reflect an elevated background in the organic-rich shales. Values ranging from 10 to $30 \mathrm{ppm}$ are characteristic of samples scattered throughout the Kenai Peninsula. The Mo in these samples shows no correlation with any other trace elements and is thus believed to represent background scatter. Samples draining the granite along the south side of Port Nellie Juan have a distinct As-Co-Cu-Mo-W-Y-Th enrichment and contain scheelite, thorite, arsenopyrite, and chalcopyrite. The two sulfides though are believed to be derived from epigenetic veins and the Mo anomaly most likely reflects a high lithologic background.

The only sample containing greater than $200 \mathrm{ppm}$ Mo is a single point anomaly on the Kenai Peninsula along the east shore of Cooper Lake within Valdez
Group metasedimentary rocks. The sample (500 ppm Mo, sample 0534; Goldfarb and others, 1984) was noted to contain wulfenite along with pyrite (R. B. Tripp, written commun., 1982). The source of the oxide mineral is unknown at the present time.

Clusters of samples containing anomalous amounts of $\mathrm{Sn}$ are, for the most part, derived from intrusive bodies north of Sheep Bay (2F), at Cedar Bay (2E), on Perry, Culross (2C), and Esther Islands (2D), around Eshamy Lagoon (2A), and along the south store of Port Nellie Juan (2B). Cassiterite has been identified in a few placer samples weathered from the Esther Island, Cedar Bay, Sheep Bay, and Eshamy Lagoon plutons (R. B. Tripp, written communs., 1982 and 1983).

Other anomalous amounts of $\mathrm{Sn}$, mostly ranning from 20 to $70 \mathrm{ppm}$, extend for $15 \mathrm{mi}$ from Graveyard Point in Port Fidalgo to the south side of Mt. Francis near the mouth of the Lowe River. A smaller cluster of Sn-rich samples occurs on moraines and in side valleys of Woodworth Glacier, just north of the contact with the metavolcanic rocks. Neither of trese two regions is associated with any known igneous rocks. Therefore, these might just reflect a local enrichment of $\mathrm{Sn}$ in the turbidite beds; cassiterite was not identified in either area. Two samples (samples 1710 and 1733; Goldfarb and others, 1984) rear Billygoat Mountain in the Port Fidalgo-Mt. Francis trend contained $1,500 \mathrm{ppm}$ and $500 \mathrm{ppm} \mathrm{Sn}$. Trese values may reflect unrecognized metal contamination from small copper mines in the area. Possibly minor amounts of $\mathrm{Sn}$ in rutile could contribute to either of the Sn enrichments. No rutile has been identified in concentrates from either of the two localities; however, we have noted rutile in polished thin sections of quartz veins from a ridge to the south side of Cleave Creek Glacier just about $8 \mathrm{mi}$ north of the Woodworth Glacier anomalous samples. -wo anomalous $S n$ values were recorded in two concentrate samples from below the ridge (samples 0932 and 0934; Goldfarb and others, 1984). Thus rutile-bearing veins might also exist within nunataks on Woodworth Glacier.

Thorium enrichment of concentrate samples within the Chugach National Forest characterizes all drainages underlain by the felsic intrusives and by the high-grade metamorphic complex east of the Cofper River. Whereas some of the anomalies are just riah background in common rock-forming minerals within felsic plutonic rocks, monazite and thorite have boen identified draining the Sheep Bay pluton, thorite was noted in samples along the south side of Port Nellie Juan, and uranothorite is contained within samples taken between Kadin and Terentiev Lake on the v'est side of Columbia Glacier (R. B. Tripp, written communs., 1982 and 1983). Maximum scintillometer readings of 250 cps were recorded for the Sheep Bay pluton, but no uranium minerals were found.

Tungsten was detected in approximately 25 percent of the heavy-mineral-concentrate samples. Samples containing anomalous amounts of $W$, corresponding fairly well to the microscopic identification of scheelite, are scattered throughout areas underlain by the metasedimentary rocks of the Valdez Group with the exception of the Port Valc'ez- 
Ellamar, upper Columbia Glacier, Girdwood, Cochrane Bay-Blackstone Bay, and most of the southern Kenai Peninsula areas. There are no obvious differences in these latter areas that would appear to make them any less favorable for the presence of scheelite than other parts of the Valdez Group.

Worldwide, scheelite tends to be associated with Au and sulfide minerals within epigenetic quartz lodes hosted by moderately metamorphosed turbidite units. Anomalous $W$ concentrations in concentrate samples exist in all regions of anomalous placer gold within the Valdez Group except near Girdwood and on the southern Kenai Peninsula. However, the distribution of anomalous amounts of $W$ is much more widespread than that of the anomalous $\mathrm{Au}-\mathrm{Ag}$ rank sums. Thus, whether most of the scheelite is hosted by Au-bearing veins, or by a more widespread generation of quartz veins, or is disseminated throughout the metasedimentary host rocks is presently unknown. Semiquantitative spectrographic analysis of Aubearing quartz veins showed almost all to contain less than $50 \mathrm{ppm} W$, but a few were seen to carry as much as $1,000 \mathrm{ppm} W$. At least some of the $W$, probably existing in scheelite, therefore is likely being derived from the Au-bearing veins.

Anomalous amounts of $W$ in concentrates are also observed to have been derived from all Tertiary felsic plutons except the Cedar Bay, Perry Island, and Culross Island plutons and the northern half of the Sheep Bay pluton. Scheelite has been positively identified (R. B. Tripp, written commun., 1983) as the dominant $W$ mineral phase in all these anomalous samples derived from igneous source rocks. Along both sides of the Copper River, anomalous amounts of $W$ are derived from areas underlain by turbidites of both the Valdez and Orca Groups. This is the only region within the Chugach National Forest where anomalous amounts of $W$ are being derived from the Orca Group. The $W$ distribution may delineate the extent of the thermal metamorphic event along the Copper River described by Miller and others (1984).

\section{REFERENCES CITED}

Cohen, A. C., 1959, Simplified estimates for the normal distribution when samples are singly censored or truncated: Technometric, v. 1, no. 3, p. 217-237.

Davis, J. C., 1973, Statistics and data analysis in geology: New York, John Wiley and Sons, 550 p.

Dumoulin, J. A., 1984, Composition and provenance of sandstone of the Orca and Valdez Groups, Prince William Sound, Alaska: Geological Society of America Abstracts with Program, v. 16, no. 5, p. 280.

Goldfarb, R. J., Leach, D. L., Miller, M. L., and Pickthorn, W. J., 1987, Geology, metamorphic setting, and genetic constraints of epigenetic lode-gold mineralization within the Cretaceous Valdez Group, south-central Alaska, in Keppie J. D., Boyle, R. W., and Haynes, $\overline{S_{\text {. }}}$ J., eds., Turbidite-hosted gold deposits: Geological Association of Canada Special Paper 32, p. 87-106.
Goldfarb, R. J., Leach, D. L., and Speckman, W. S., 1983, An application of rank-order statistics to exploration geochemistry [abs.]: 10th International Geochemical Exploration Symposium, 3rd Symposium on Methods of Geochemical Prospecting, Espoo/Helsinki, Finland, Prngrams and Abstracts, p. 30.

Goldfarb, R. J., Nelson, S. W., Dumoulin, J. A., Miller, M. L., with contributions from Day, Gordon, Hoffman, James, Tripp, Richard, Smaglik, Suzanne, and Folger, Peter, 1984, Data report and statistical summary for samples of moraine and stream sediment, nonmagnetic heavymineral concentrate, and rock from the Chugach National Forest, Alaska: U.S. Geological Survey Open-File Report 84-355, 446 p.

Goldfarb, R. J., and Tripp, R. B., 1985, Geochemical map showing distribution of chalcopyrite within the Chugach National Forest, Alaska: U.S. Geological Survey Miscellaneous Field Studies Map MF-1645-E, scale $1: 250,000$.

Goldfarb, R. J., Tripp, R. B., and Smaglik, S. M., 1985, Geochemical map showing distribution of barite, galena, and sphalerite within the Chugach National Forest, Alaska: U.S. Geological Survey Miscellaneous Field Studies Map MF-1645-C, scale $1: 250,000$.

Grimes, D. J., and Marranzino, A. P., 1968, Direct current arc and alternating current spark emission spectrographic field methois for semiquantitative analysis of geologic meterials: U.S. Geological Survey Circular 591, $6 \mathrm{p}$.

Hudson, Travis, and Plafker, George, 1982, Paleogene metamorphism of an accretionary flysch terrane, eastern Gulf of Alaska: Geological Society of America Bulletin, v. 93, p. 1280-1290.

Hudson, Travis, Plafker, George, and Petermar. Z. E., 1979, Paleogene anatexis along the Gulf of Alaska margin: Geology, v. 7, p. 573-577.

Jansons, Uldis, Hoekzema, R. B, Kurtuk, J. M., and Fechner, S. A, 1984, Mineral occurrences in the Chugach National Forest, south-central Alaska: U.S. Bureau of Mines Open-File Report MLA, 584.

Johnston, R. J., 1980, Multivariate statistical analysis in geography: London, Longman Group Limited, $280 \mathrm{p}$.

Joreskog, K. G., Klovan, J. E., and Reyment, R. A., 1976, Geological factor analysis: Amsterdam, The Netherlands, Elsevier Scientific Publishing Company, $178 \mathrm{p}$.

Koski, R. A., Silberman, M. L., Nelson, S. W., and Dumoulin, J. A., 1985, Rua Cove--Anatomy of volcanogenic $\mathrm{Fe}-\mathrm{Cu}$ sulfide deposit in oxhiolite on Knight Island, Alaska: American Association of Petroleum Geologists, Program and Ab-tracts, Pacific Section, p. 63.

Kupcik, V., Ahrens, L. H., Erlank, A. J., and Wedepohl, K. H., 1972, Bismuth, in Handbnok of geochemistry: Berlin, Springer-Verlag. v. II, sections 83-A-0.

Lanphere, M. A., 1966, Potassium-argon ages of Tertiary plutons in the Prince Williarr Sound region, Alaska, in Geological Survey rosearch 1966, Chapter D: U.S. Geological Survey Professional Paper 550-D, p. D195-D198. 
Leach, D. L., and Goldfarb, R. J., in press, Maps showing the distribution of the sum of the ranks for concentrates of lead and zinc, and copper, silver, lead, and zinc in samples of stream sediment from the Wallace $1^{0} \times 2^{\circ}$ quadrangle, Idaho: U.S. Geological Survey Miscellaneous Field Studies Map MF-1354-D.

Miesch, A. T., 1976, Geochemical survey of Missouri-Methods of sampling, laboratory analysis, and statistical reduction of data: U.S. Geological Survey Professional Paper 954-A, p. Al-A39.

Miesch, A. T., and VanTrump, George, Jr., 1977, The U.S. Geological Survey RASS-STATPAC system for management and statistical reduction of geochemical data: Computers and Geosciences, v. 3, p. 479-488.

Miller, M. L., Dumoulin, J. A., and Nelson, S. W., 1984, A transect of metamorphic rocks along the Copper River, Cordova and Valdez quadrangles, in Reed, K. M., and Bartsch-Winkler, Susan, eds., The U.S. Geological Survey in Alaska-Accomplishments during 1982: U.S. Geological Survey Circular 939, p. 52-53.

Moffit, F. H., and Fellows, R. E., 1950, Copper deposits of the Prince William Sound district, Alaska: U.S. Geological Survey Bulletin 963-B, p. 47-80.

Motooka, J. M., and Grimes, D. J., 1976, Analytical precision of one-sixth order semiquantitative spectrographic analyses: U.S. Geological Survey Circular 738, 25 p.

Nelson, S. W., Dumoulin, J. A., and Miller, Marti, 1984, Geologic map of the Chugach National Forest, Alaska: U.S. Geological Survey Miscellaneous Field Studies Map MF-1645-B, scale 1:250,000.

Nelson, S. W., Miller, M. L., Barnes, D. F., Dumoulin, J. A., Goldfarb, R. J., Koski, R. A., Mull, C. G., Pickthorn, W. J., Jansons, Uldis, Hoekzema, R. B., Kurtak, J. M., and Fechner, S. A., 1984, Mineral resource potential map of the Chugach National Forest, Alaska: U.S. Geological Survey Miscellaneous Field Studies Map MF-1645-A, scale $1: 250,000$.

Pickthorn, W. J., Goldfarb, R. J., O'Leary, R. M., Sutley, S. J., and Weaver, S. C., 1985, Kayak Island--Analysis of a geochemical anomaly, in Bartsch-Winkler, Susan, and Reed, K. M., eds., The U.S. Geological Survey in Alaska-Accomplishments during 1983: U.S. Geological Survey Circular 945, p. 82-83.
Plafker, George, 1971, Possible future petroleum resources of Pacific-margin Tertiary basins, Alaska, in Future petroleum provinces of North America: American Association of Petroleum Geologists, Memoir 15, p. 120-135.

Plafker, George, 1974, Preliminary geologic map of Kayak and Wingham Islands, Alaska: U.S. Geological Survey Open-File Report 74-82, scale $1: 31,680$.

Plafker, George, Jones, D. L., and Pessagna, E. A., Jr., 1977, A Cretaceous accretionary flysct and melange terrane along the Gulf of $f$ laska margin, in Bleam, K. M., ed., The U.S. Geological Survey in Alaska--Accomplishments during 1976: U.S. Geological Survey Circular $751-B$, p. B41-B43.

Plafker, George, and Lanphere, M. A., 1974, Radiometrically dated plutons cutting the Orca Group, in Carter, Claire, ed., U.S. Geological Survey Alaska Program, 1974: U.S. Geological Survey Circular 700, p. 5.

Tripp, R. B., Goldfarb, R. J., and Pickthorn, W. J., 1985, Geochemical map showing distribution of gold within the Chugach National Forest, Alaska: U.S. Geological Survey Miscellaneous Field Studies Map MF-1645-D, scale 1:250,0า0.

Tukey, J. W., 1977, Exploration data analysis: New York, Addison-Wesley, $250 \mathrm{p}$.

Tysdal, R. G., and Case, J. E., 1979, Geologic map of the Seward and Blying Sound quadrangles, Alaska: U.S. Geological Survey Miscellaneous Investigations Series Map I-1150, scale 1:250,000.

Wahrhaftig, Clyde, 1965, Physiographic divisions of Alaska: U.S. Geological Survey Profes?ional Paper 482, $52 \mathrm{p}$.

Winkler, G. R., Miller, R. J., Mackevett, E. M.. Jr., and Holloway, C. D., 1981, Map and summary table describing mineral deposits in the Valdez quadrangle, southern Alaska: U.S. Geological Survey Open-File Report 80-892-B, scale $1: 250,000,2$ sheets.

Winkler, G. R., and Plafker, George, 1975, The Landlock fault--Part of a major early Tertiary plate boundary in southern Alaska, in Yount, $M$. E., ed., U.S. Geological Survey Alaska Prozram, 1975: U.S. Geological Survey Circular 722, p. 49.

Winkler, G. R., and Plafker, George, 1981, Ge logic map and cross sections of the Cordova and Middleton Island quadrangles, southern Alaska: U.S. Geological Survey Open-File Report 811164, 26 p. 

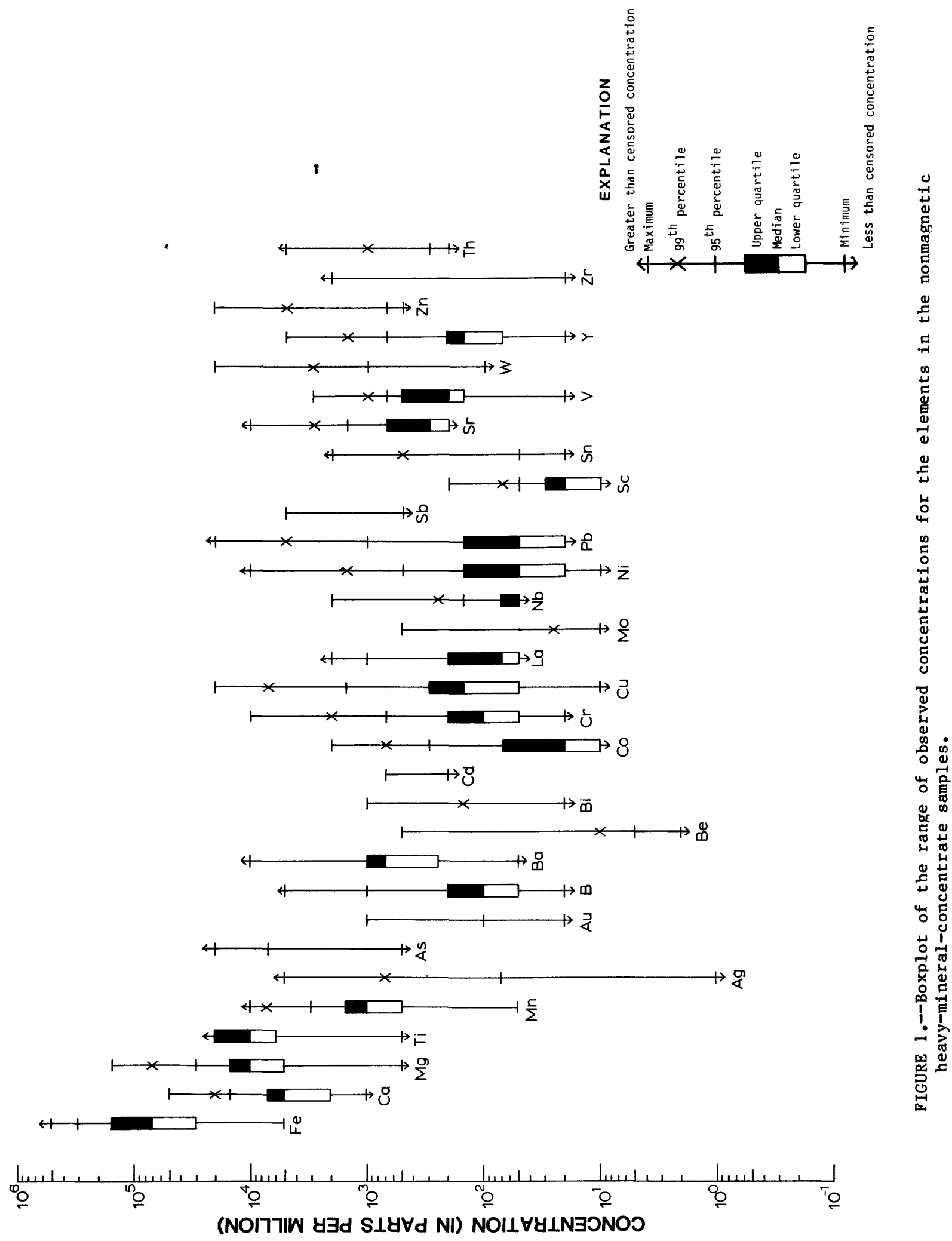

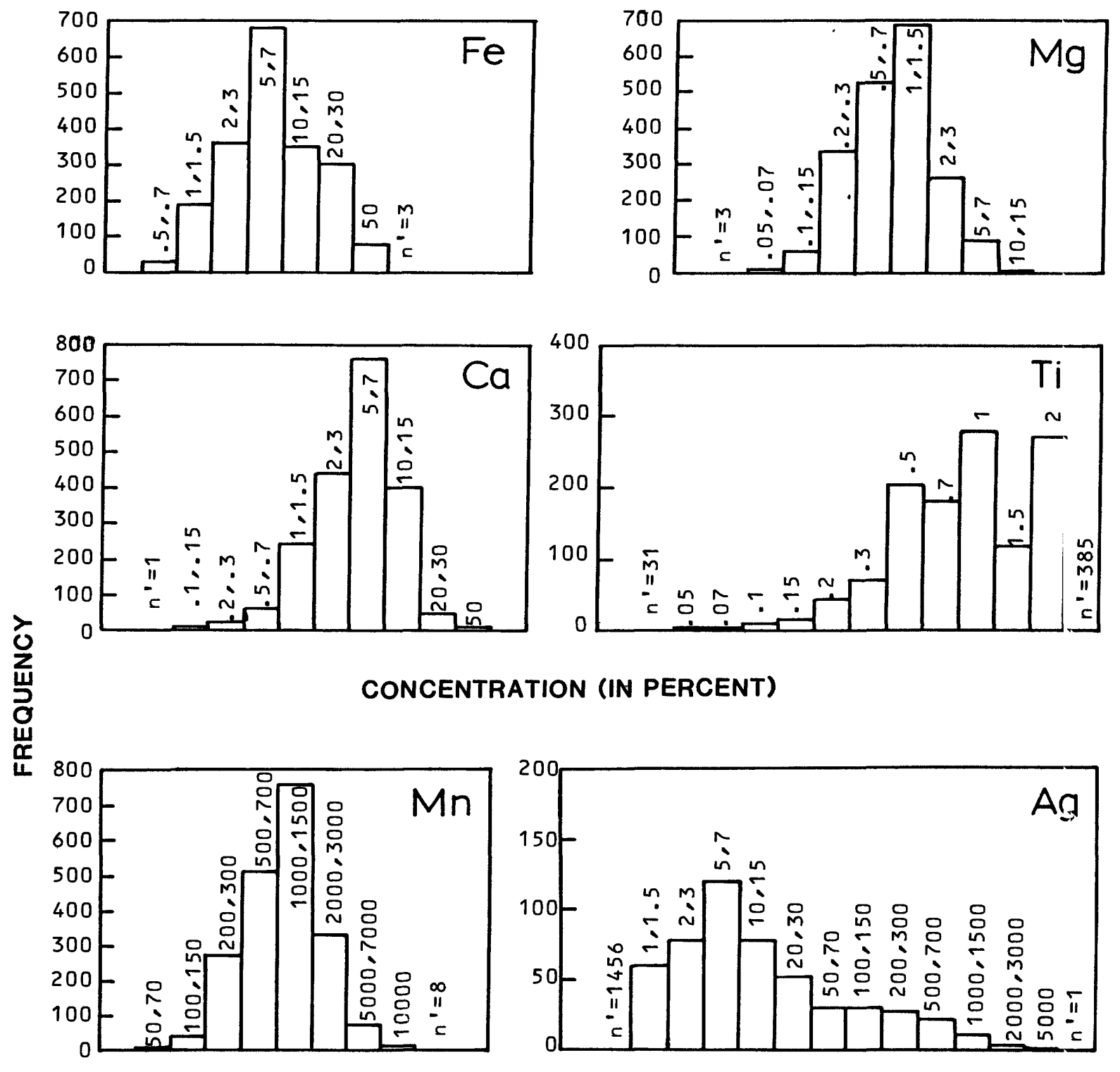

\section{CONCENTRATION (IN PERCENT)}
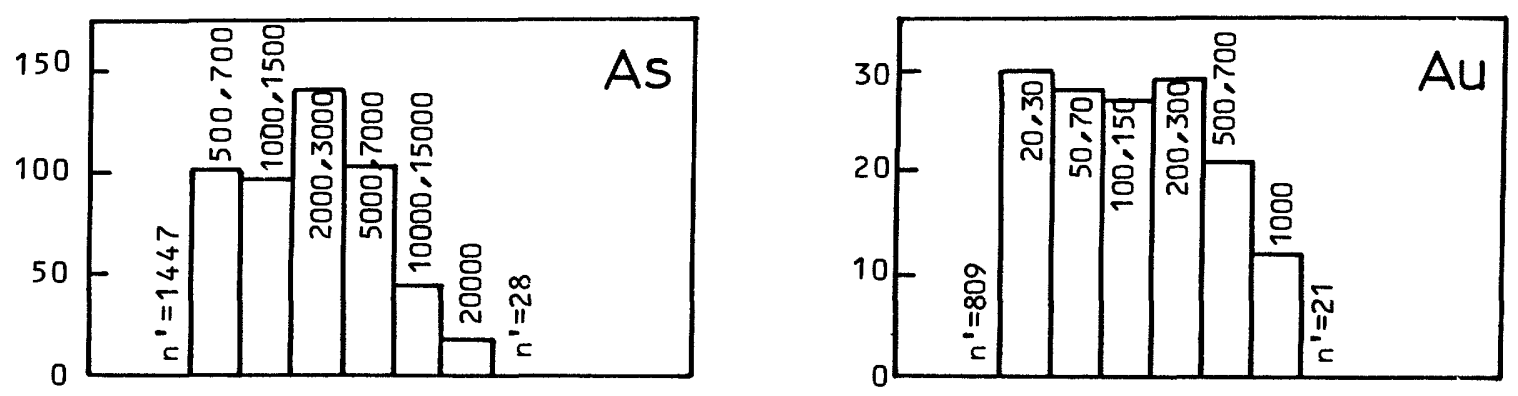

\section{CONCENTRATION (IN PARTS PER MILLION)}

FIGURE 2.-Histograms showing frequency distribution for nonmagnetic heavy-mineral-concentrate samples. The number of samples below the determination limit is indicated by " $n$ " at the left of the histograms, whereas the number of samples that exceed the determination limit is indicated by " $\mathrm{n}$ "" at the right of the histograms. 

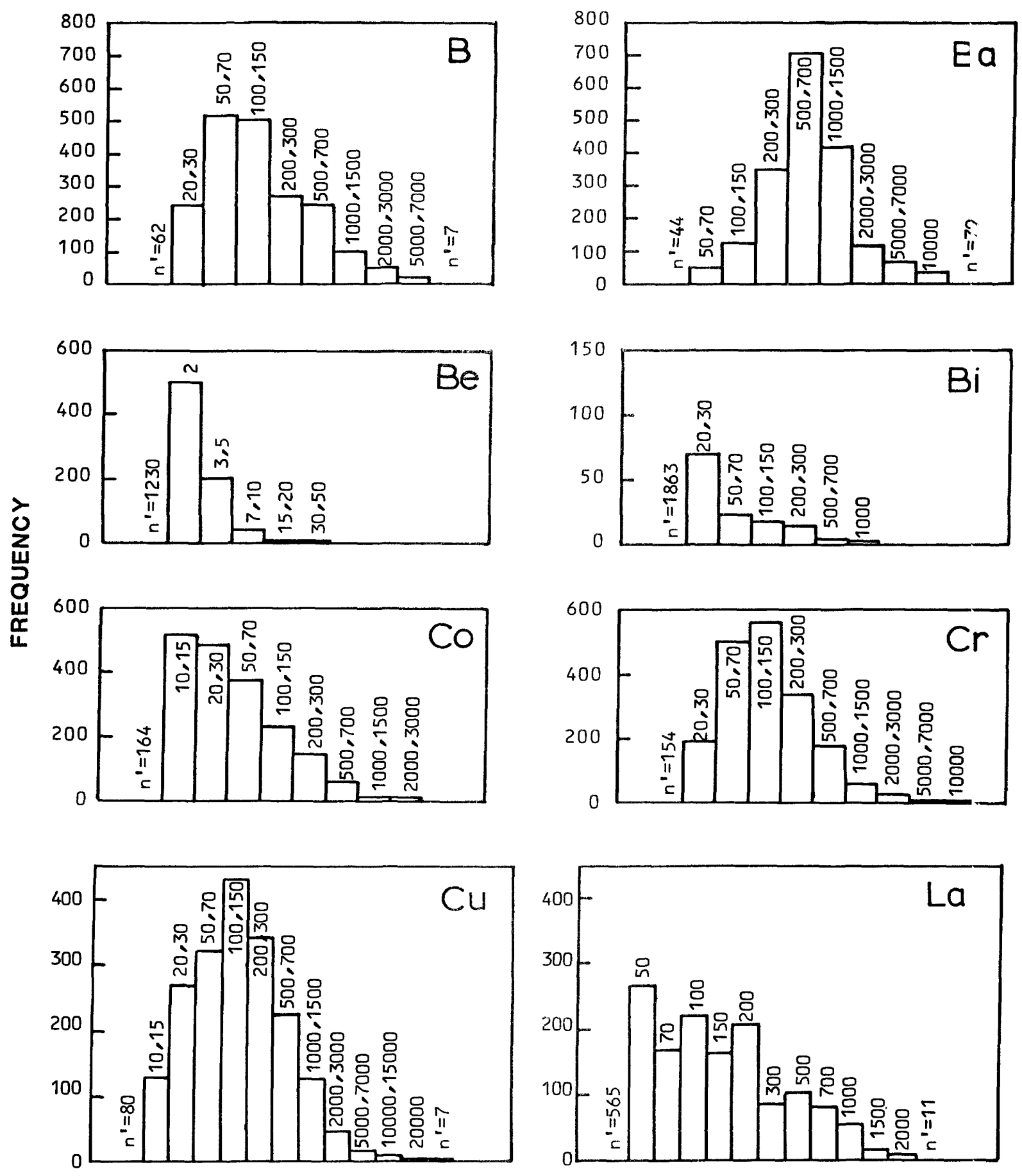

CONCENTRATION (IN PARTS PER MILLION)

FIGURE 2.--Histograms showing frequency distribution for nonmagnetic heavy-mineral-concentrate samples--Continued 

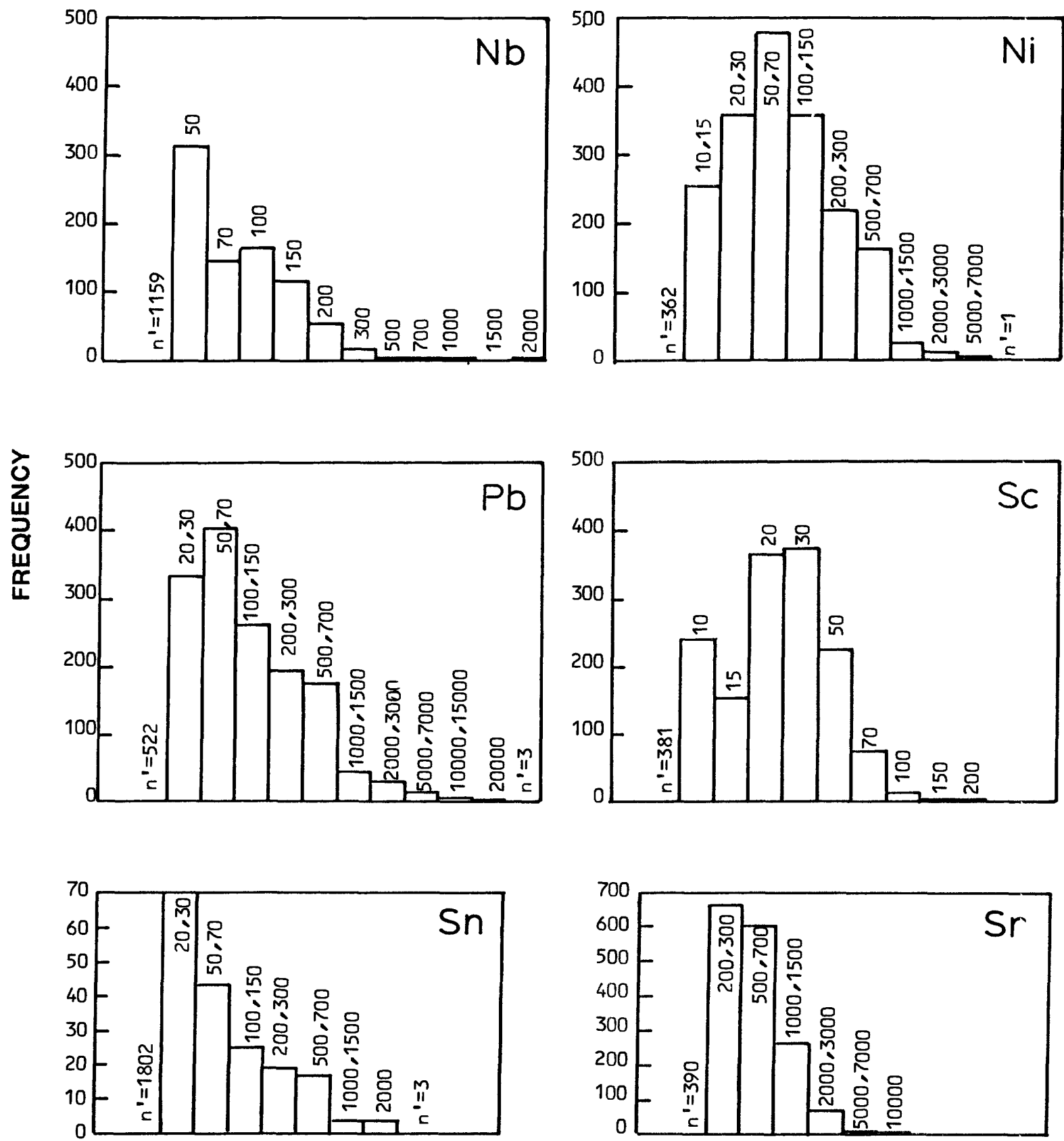

\section{CONCENTRATION (IN PARTS PER MILLION)}

FIGURE 2.--Histograms showing frequency distribution for nonmagnetic heavy-mineral-concentrate samples-Continued 

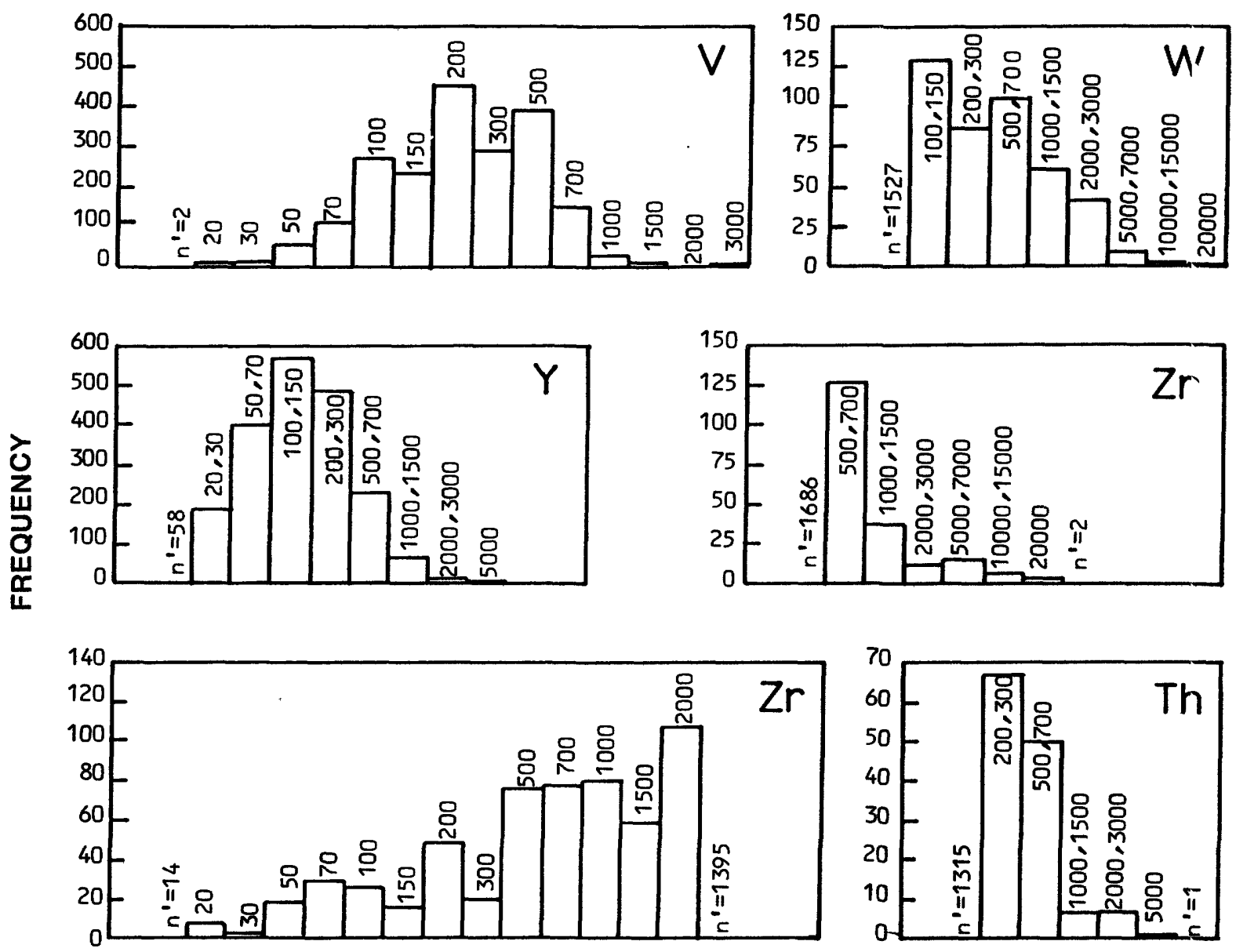

\section{CONCENTRATION (IN PARTS PER MILLION)}

FIGURE 2.--Histograms showing frequency distribution for nonmagnetic heavy-mineral-concentrate samples--Continued 
TABLE 1.--Univariate statistical estimates for elements in 1,979 nonmagnetic heavy-mi neral-concentrate samples

[Al1 values in parts per million, except geometric mean, geometric deviation, and expected range for $\mathrm{Fe}, \mathrm{Mg}, \mathrm{Ca}$, and $\mathrm{Ti}$ are in percent. Leaders (-), no data. All elements were determined by semiquantitative emission spectrography]

\begin{tabular}{|c|c|c|c|c|c|c|c|c|}
\hline Element & $\begin{array}{l}\text { Detection } \\
\text { ratio }\end{array}$ & $\mathrm{N}^{2}$ & $\mathrm{~L}^{3}$ & $\mathrm{G}^{4}$ & $\mathrm{~B}^{5}$ & $\begin{array}{c}\text { Geometric } \\
\text { mean }\end{array}$ & $\begin{array}{l}\text { Geometric } \\
\text { deviation }\end{array}$ & $\begin{array}{l}\text { Expected } \\
\text { range } 6\end{array}$ \\
\hline $\mathrm{Fe}$ & .99 & 0 & 0 & 3 & 1 & 6.4 & 2.8 & $0.80-51$ \\
\hline $\mathrm{Mg}$ & .99 & 0 & 3 & 0 & 2 & 0.82 & 2.5 & $0.13-5.2$ \\
\hline $\mathrm{Ca}$ & .99 & 0 & 1 & 0 & 23 & 4.0 & 2.6 & $0.60-27$ \\
\hline $\mathrm{Ti}$ & .63 & 30 & 0 & 684 & 31 & 1.6 & 4.4 & $0.084-31$ \\
\hline Mn & .99 & 0 & 0 & 9 & 1 & 960 & 2.4 & $170-5,500$ \\
\hline $\mathrm{Ag}$ & .26 & 1,411 & 50 & 1 & 1 & - & -- & -- \\
\hline As & .26 & 1,425 & 26 & 34 & 0 & - & - & - \\
\hline $\mathrm{Au}$ & .08 & 1,796 & 14 & 27 & 2 & - & -- & - \\
\hline B & .97 & 5 & 49 & 7 & 1 & 120 & 3.6 & $9.6-1,600$ \\
\hline $\mathrm{Ba}$ & .94 & 20 & 23 & 86 & 1 & 670 & 3.6 & $51-8,700$ \\
\hline $\mathrm{Be}$ & .38 & 785 & 430 & 0 & 0 & - & - & -- \\
\hline $\mathbf{B i}$ & .06 & 1,777 & 85 & 0 & 1 & - & -- & -- \\
\hline $\mathrm{Cd}$ & .01 & 1,934 & 4 & 0 & 27 & -- & - & -- \\
\hline Co & .92 & 89 & 82 & 0 & 0 & 32 & 3.4 & $2.7-360$ \\
\hline $\mathrm{Cr}$ & .93 & 46 & 105 & 0 & 1 & 100 & 3.4 & $9.3-1,200$ \\
\hline $\mathrm{Cu}$ & .96 & 23 & 58 & 1 & 0 & 120 & 4.7 & $5.3-2,600$ \\
\hline La & .70 & 504 & 52 & 11 & 24 & 91 & 3.7 & $6.8-1,200$ \\
\hline Mo & .02 & 1,877 & 32 & 0 & 22 & -- & -- & - \\
\hline $\mathrm{Nb}$ & .42 & 851 & 277 & 0 & 3 & - & - & -- \\
\hline $\mathrm{Ni}$ & .92 & 138 & 25 & 1 & 9 & 53 & 4.0 & $3.3-840$ \\
\hline $\mathrm{Pb}$ & .73 & 241 & 264 & 0 & 0 & 50 & 5.5 & $1.6-1,500$ \\
\hline $\mathrm{Sb}$ & .01 & 1,946 & 9 & 0 & 2 & - & -- & -- \\
\hline Sc & .79 & 293 & 85 & 0 & 171 & 18 & 2.15 & $4.0-85$ \\
\hline $\mathrm{Sn}$ & .09 & 1,756 & 41 & 3 & 0 & - & - & -- \\
\hline $\mathrm{Sr}$ & .81 & 253 & 99 & 0 & 1 & 350 & 2.43 & $60-2,100$ \\
\hline V & .99 & 1 & 0 & 0 & 1 & 230 & 2.14 & $50-1,000$ \\
\hline W & .23 & 1,449 & 70 & 1 & 0 & - & - & - \\
\hline $\mathrm{Y}$ & .97 & 26 & 28 & 0 & 1 & 130 & 2.9 & $15-1,100$ \\
\hline $\mathrm{Zn}$ & .10 & 1,641 & 131 & 1 & 0 & - & -- & - \\
\hline $\mathrm{Zr}$ & .28 & 14 & 0 & 1,399 & 1 & -- & -- & -- \\
\hline Th & .09 & 1,251 & 60 & 1 & 533 & - & - & -- \\
\hline
\end{tabular}

${ }^{1}$ Detection ratio is the number of uncensored concentrations divided by the total number of samples analyzed for a given element.

${ }^{2} \mathrm{~N}$ is the number of samples in which concentrations could not be detected at the lower determination limit.

${ }^{3} \mathrm{~L}$ is the number of samples in which concentrations were reported as observable but were less than the lower determination limit.

${ }^{4} G$ is the number of samples in which concentrations were reported as observable but were greater than the upper determination limit.

$5_{B}$ is the number of samples in which the element was not analyzed.

6 Expected range is the distribution of 95 percent of all data expected for 1 og normal data. 
TABLE 2.--Threshold concentrations and percentiles of selected elements in nonmagnetic heavy-mineral concentrate samples

[All threshold concentrations in parts per million, except Fe in percent]

\begin{tabular}{lrrrrr}
\hline Element & $\begin{array}{c}\text { Threshold } \\
\text { concentration }\end{array}$ & Percentile & Element & $\begin{array}{c}\text { Threshold } \\
\text { concentration }\end{array}$ & Percentile \\
\hline $\mathrm{Fe}$ & 50 & 95.8 & $\mathrm{Cr}$ & 1,000 & 95.3 \\
$\mathrm{Mn}$ & 5,000 & 95.4 & $\mathrm{Cu}$ & 1,500 & 93.6 \\
$\mathrm{Ag}$ & 10 & 87.4 & $\mathrm{Mo}$ & 10 & 97.8 \\
$\mathrm{As}$ & 2,000 & 83.1 & $\mathrm{Ni}$ & 1,000 & 97.8 \\
$\mathrm{Au}$ & 20 & 91.5 & $\mathrm{~Pb}$ & 1,000 & 94.5 \\
& & & & & \\
$\mathrm{~B}$ & 1,000 & 91.4 & $\mathrm{Sb}$ & 500 & 99.1 \\
$\mathrm{Ba}$ & 2,000 & 84.5 & $\mathrm{Sn}$ & 30 & 93.2 \\
$\mathrm{Be}$ & 5 & 90.3 & $\mathrm{~W}$ & 1,000 & 94.0 \\
$\mathrm{Bi}$ & 20 & 93.8 & $\mathrm{Zn}$ & 700 & 94.3 \\
$\mathrm{Cd}$ & 200 & 99.7 & $\mathrm{Th}$ & 300 & 94.3 \\
$\mathrm{Co}$ & 300 & 94.4 & & & \\
\hline
\end{tabular}


TABLE 3.--Factor loadings for the first six factors after varimax rotation of the residual heavy-mineral-concentrate samples

[Total variance explained by the six factors equals 60.7 percent. Leaders (-), loadings less than $|0.30|$ that have been omitted]

\begin{tabular}{|c|c|c|c|c|c|c|}
\hline \multirow{2}{*}{ Element } & \multicolumn{6}{|c|}{ Factors } \\
\hline & 1 & 2 & 3 & 4 & 5 & 6 \\
\hline $\mathrm{Fe}$ & 0.75 & - & - & -- & -- & - \\
\hline $\mathrm{Mg}$ & -- & -0.61 & -- & -- & -- & -0.42 \\
\hline $\mathrm{Ca}$ & -- & - & 0.78 & - & -- & - \\
\hline Mn & -- & -- & - & - & - & -0.62 \\
\hline $\mathrm{Ag}$ & -- & -- & - & -- & - & 0.73 \\
\hline As & -- & -- & -- & - & - & 0.69 \\
\hline B & -- & - & -- & -- & 0.82 & - \\
\hline $\mathrm{Ba}$ & -- & -- & -0.32 & 0.65 & - & -- \\
\hline $\mathrm{Be}$ & - & -- & -- & 0.32 & 0.58 & - \\
\hline Co & 0.66 & -- & -- & -- & - & 0.46 \\
\hline $\mathrm{Cr}$ & -0.53 & -0.46 & - & - & - & - \\
\hline $\mathrm{Cu}$ & 0.64 & -- & -- & - & - & -- \\
\hline La & -0.38 & 0.57 & -- & - & - & - \\
\hline $\mathrm{Nb}$ & -- & 0.63 & -- & -- & -- & - \\
\hline $\mathrm{Ni}$ & 0.66 & - & -0.31 & - & - & 0.32 \\
\hline $\mathrm{Pb}$ & - & -- & -- & -- & - & 0.70 \\
\hline $\mathrm{Sc}$ & -0.69 & - & - & -- & -- & - \\
\hline $\mathrm{Sr}$ & - & - & -- & 0.81 & - & - \\
\hline V & -- & -- & 0.42 & -- & -- & -0.55 \\
\hline W & -- & -- & 0.34 & - & - & -- \\
\hline $\mathbf{Y}$ & -0.34 & 0.80 & -- & -- & - & -- \\
\hline $\mathrm{Zn}$ & -- & - & -0.54 & 0.32 & - & -- \\
\hline $\mathrm{Zr}$ & -- & 0.67 & - & -- & - & - \\
\hline $\begin{array}{l}\text { Percent of total } \\
\text { variance explained } \\
\text { by factor- }\end{array}$ & 22.2 & 14.8 & 7.7 & 6.6 & 4.8 & 4.6 \\
\hline
\end{tabular}

